\title{
IMPLEMENTASI PERATURAN PRESIDEN NOMOR 125 TAHUN 2012 TENTANG PENATAAN DAN PEMBERDAYAAN PEDAGANG KAKI LIMA DI KOTA PALEMBANG
}

\author{
Rizki Ramadhani \\ Fakultas Hukum Universitas Kader Bangsa
}

rizkyrd22@gmail.com

\begin{abstract}
ABSTRAK
Penelitian ini dilatarbelakangi oleh adanya Peraturan Presiden Nomor 125 Tahun 2012 tentang Koordinasi Penataan dan Pemberdayaan Pedagang Kaki Lima namun penerapannya belum dirasakan sepenuhnya oleh setiap masyarakat di Indonesia, salah satunya pada masyarakat di Palembang. Pelaksanaan peraturan tersebut dilakukan secara yuridis dan institusional. Penelitian ini merupakan penelitian hukum empiris dengan pendekatan perundang-undangan, pendekatan sosiolegal dan pendekatan konseptual dengan sumber bahan hukum yang dipergunakan adalah bahan hukum primer, sekunder dan tersier melalui penelitian secara langsung di Pasar 16 Ilir Kota Palembang mellaui studi kepustakaan dan wawancara pada Dinas Perdaganga serta Satpol PP Kota Palembang dengan analisis deskriptif kualitatif dengan menarik kesimpulan secara deduktif. Berdasarkan penelitian ini dapat diketahui bahwa implementasi Perpres Nomor 125 Tahun 2012 tentang Penataan dan Pemberdayaan PKL Kota Palembang belum sepenuhnya berjalan baik. Penegakan Hukum Terhadap Koordinasi di Kota Palembang setelah Perpres Nomor 125 Tahun 2012 tentang Koordinasi Penataan dan Pemberdayaan PKL di Kota Palembang kawasan pasar 16 ilir dilakukan dengan memberlakukan sanksi administrasi.
\end{abstract}

Kata kunci: Pedagang Kaki Lima, Peraturan Presiden, Kota Palembang.

\section{ABSTRACT}

This research is motivated by the existence of Presidential Regulation Number 125 of 2012 concerning Coordination of Arrangement and Empowerment of Street Vendors but its implementation has not been fully felt by every community in Indonesia, one of which is the people in Palembang. The implementation of these regulations is carried out legally and institutionally. This research is empirical legal research with a statutory approach, a socio-legal approach and a conceptual approach with the sources of legal materials used are primary, secondary, and tertiary legal materials through direct research at Pasar 16 Ilir Palembang City through literature studies and interviews at the Dinas Trade and Satpol PP Palembang City with a qualitative descriptive analysis by drawing deductive conclusions. Based on this research, it can be seen that the implementation of Presidential Regulation No. 125 of 2012 concerning the Arrangement and Empowerment of PKL Korespondensi:

Palembang City has not fully gone well. Law Enforcement on Coordination in Palembang City after

Universitas Kader Bangsa (UKB)

Jl. Mayjen HM Ryacudu No.88, 7 Ulu, Kecamatan

Seberang Ulu I, Kota Palembang.

JURNAL ILMIAH DINAMIKA SOSIAL 4 (1) 2020 172

E-mail: rizkyrd22@gmail.com 
Presidential Decree No. 125 of 2012 concerning Coordination of Arrangement and Empowerment of Street Vendors in Palembang City in the 16 ilir market area was carried out by imposing administrative sanctions.

Keywords: Street Vendors, Presidential Regulation, Palembang City.

\section{PENDAHULUAN}

Palembang merupakan kota terbesar kedua di Sumatera setelah Medan. Hal ini terbukti dari jumlah penduduk kota Palembang yang berjumlah hampir dua juta jiwa. Kota Palembang mengalami peningkatan jumlah penduduk yang pesat setiap tahunnya. kota Palembang yang merupakan kota metropolitan adalah salah satu alasan banyaknya jumlah penduduk yang setiap tahunnya baik itu dari penduduk yang datang dari luar Pulau Sumatera untuk mencari pekerjaan. Banyaknya jumlah penduduk yang datang dari setiap daerah luar kota Palembang tidak diimbangi dengan jumlah lapangan pekerjaan yang memadai (Wikipedia, 2017). Hal ini mengakibatkan peningkatan atas jumlah pengangguranpengangguran di kota Palembang. Pendidikan yang rendah serta lapangan pekerjaan yang tidak memadai menjadi alasan bagi masyarakat untuk memilih usah di sektor informal dengan cara berdagang melalui modal yang tidak besar demi menunjang kebutuhan hidupnya. Salah satu usaha di sektor informal dengan cara berdagang melalui modal yang kecil adalah dengan menjadi pedagang kaki lima.

Berdasarkan Peraturan Presiden Republik Indonesia Nomor 125 Tahun 2012 Tentang Koordinasi Penataan dan Pemberdayaan Pedagang Kaki Lima, Pedagang kaki lima adalah pelaku usaha yang melakukan usaha perdagangan dengan menggunakan sarana usaha bergerak maupun tidak bergerak, menggunakan prasarana kota, fasilitas sosial, fasilitas umum, lahan dan bangunan milik pemerintah dan/atau swasta yang bersifat sementara/tidak menetap. Kehadiran pedagang kaki lima di kota Palembang sudah tidak dapat dihindari atau ditiadakan lagi. Pedagang Kaki Lima dengan modal yang kecil hanya dapat menjual berbagai macam dagangannya, jenis dagangannya pun berupa makanan yang tidak atau belum diproses seperti daging, buah-buahan, sayuran, dan makanan yang sudah diproses seperti lauk pauk dan minuman. Selain hal tersebut pedagang kaki lima dapat juga menjual barang tekstil, obat obatan, dan jasa yang dijual padagang kaki lima berupa pangkas rambut dan sol sepatu. Namun pedagang kaki lima juga memiliki karakteristik dan masalah tersendiri, yakni salah satunya kurangnya memperhatikan kebersihan lingkungan tempat berdagang, dan berlokasi di tempat yang padat (Firdausy, 1995). Pedagang kaki lima banyak menjajakan dagangannya di tempat-tempat umum seperti di stasiun kereta api, pasar tradisional, halte-halte, tempat 
pariwisata dan tempat-tempat keramaian lainnya dengan menggunakan gerobak atau bahkan dengan beralaskan terpal (Permadi, 2007).

Keberadaan Pedagang kaki lima merupakan salah satu jalan keluar yang ditempuh untuk mengatasi pengangguran di kota Palembang dan juga bisa menambah pendapatan perkapita penduduk jika para pedagang kaki lima tersebut melakukan usahanya dengan baik. Pedagang kaki lima di kota Palembang berkembang semakin pesat setiap tahunnya. Semakin berkembangnya pedagang kaki lima yang ada di kota Palembang semakin banyak pula permasalahan-permasalahan yang timbul. Permasalahan-permasalahan yang sering terjadi di kota Palembang dari hari ke hari adalah kepadatan lalu lintas dimana para pedagang kaki lima menjajakan dagangannya ditempat yang mengganggu arus lalu lintas, kurangnya tingkat kesadaran pedagang kaki lima untuk kebersihan disekitar lapak dagangannya, banyaknya pedagang kaki lima yang tidak tertib, serta gangguan keamanan. Selain itu, Pedagang Kaki Lima di kota Palembang cenderung melakukan usaha dengan segala cara tanpa memperhatikan keselamatan para pembeli demi mendapat keuntungan. Bila hal ini tetap dibiarkan, maka keberadaan pedagang kaki lima akan menimbulkan permasalahan di ruang publik baik itu dibidang pembangunan, tata ruang, maupun ketertiban umum (Hukum Online, 2011).

Pedagang kaki lima tidak dapat dipisahkan dari kompleksitas pembangunan perkotaan, dengan modal yang minimum dan lokasi usaha yang mendekati konsumen, hal inilah yang menjadi ciri khas dari pedagang kaki lima yang membuat pedagang kaki lima bertahan dalam menghadapi krisis ekonomi yang sedang terjadi. Berkaitan dengan hal tersebut maka perlu dilaksanakannya penertiban dan penataan pedagang kaki lima secara bijaksana dan terkoordinasi dengan baik agar para pihak tidak ada yang dirugikan antara pedagang kaki lima dan ruang public yang digunakan agar dapat menata ruang public yang optimal sehingga dapat menyediakan ruang aktivitas yang memadai baik dari segi kualitas maupun kuantitas, sehingga ruang public tersebut dapat berfungsi sebagai mana semestinya dimana setiap orang mempunyai kesempatan yang sama untuk dapat menikmati dan melakukan aktivitas semestinya.

Keberadaan pedagang kaki lima di Palembang telah menjadi dilema yang tidak hanya menimbulkan Pro-Kontra, demonstrasi, bentrok antarwarga maupun antara warga dan aparat. 
Berkenaan dengan hal tersebut Pemerintah juga mengalami permasalahan atas keberadaan PKL. Terdapat 3 pilihan untuk mengatasi permasalahan pedagang kaki lima, yaitu Negara harus menjadi kunci utama penggerak pedagang kaki lima, organisasi pedagang kaki lima diberi ruang untuk mengatur kegiatan mereka sendiri, atau melakukan negosiasi lokasi-lokasi beroperasinya pedagang kaki lima antara pemerintah dengan pedagang kaki lima (Pena, 1999).

Dalam upaya penataan dan pemberdayaan pedagang kaki lima di Kota Palembang, Pemerintah Pusat dan Pemerintah Daerah Kota Palembang memiliki kewajiban untuk melakukan tindakan penataan dan pemberdayaan pedagang kaki lima di kota Palembang. Hal ini selaras dengan diterbitkannya Peraturan Presiden Nomor 125 Tahun 2012 Tentang Koordinasi Penataan dan Pemberdayaan Pedagang Kaki Lima. Realitasnya penerapan Peraturan Presiden Nomor 125 Tahun 2012 Tentang Koordinasi Penataan dan Pemberdayaan Pedagang Kaki Lima belum dapat dirasakan sepenuhnya oleh setiap masyarakat di Indonesia, salah satunya pada masyarakat di Palembang. Hal ini terlihat jelas dari banyaknya Pedagang Kaki Lima yang masih berjualan disembarang tempat yang menandakan bahwa Pemerintah Kota Palembang belum menyediakan fasilitas yang memadai serta belum sepenuhnya melakukan relokasi bagi Pedagang Kaki Lima di Kota Palembang sesuai dengan yang diamanatkan dalam Peraturan Presiden Nomor 125 Tahun 2012 Tentang Koordinasi Penataan dan Pemberdayaan Pedagang Kaki Lima.

Perpres Nomor 125 Tahun 2012 Tentang Koordinasi Penataan dan Pemberdayaan Pedagang Kaki Lima, Pemerintah pusat dengan pemerintah daerah khususnya Pemerintah Kota Palembang harus berkoordinasi melalui Perda Kota Palembang Nomor 13 Tahun 2007 Tentang Perubahan Atas Peraturan Daerah Kota Palembang Nomor 44 Tahun 2002 Tentang Ketentraman dan Ketertiban untuk melakukan pemberdayaan kepada para pedagang kaki lima di Kota Palembang demi mewujudkan kesejahteraan masyarakat kota Palembang dan mengembalikan ruang publik kembali menjadi tertib dan tentram sebagaimana semestinya. Dalam hal ini pula penanganan pemberdayaan pedagang kaki lima harus dilakukan guna mendapatkan kepastian hukum untuk fasilitas-fasilitas umum yang biasanya digunakan oleh pedagang kaki lima di kota Palembang.

KAJIAN TEORI (Huruf kapital, Times New Roman 12, Bold, Justify, 1 Kolom) 
Berisikan teori/konsep/pendekatan/cara pandang/perspektif/paradigm, dsb yang akan digunakan untuk menganalisis kasus atau topik yang diangkat. Penamaan kerangka analisis boleh disesuaikan atau diganti dengan menggunakan nama/istilah yang mencerminkan kerangka konseptual atau teoritik yang akan digunakan (contoh: Realisme Defensif / Defensive Realism).

\section{METODE PENELITIAN}

Penelitian ini tergolong penelitian hukum empiris. Penelitian hukum empiris adalah suatu metode penelitian yang berfokus pada pengumpulan fakta-fakta hukum atau permasalahan hukum secara terstruktur dan memperoleh materi hukum positif secara nyata (Nasution, 2008). Penelitian hukum empiris dalam penelitian ini digunakan karena hendak mencari dan mengetahui implementasi Perpres Nomor 125 Tahun 2012 Tentang Koordinasi Penataan dan Pemberdayaan PKL di Kota Palembang dan sejauh mana penegakan hukum Perpres Nomor 125 Tahun 2012 Tentang Koordinasi Penataan dan Pemberdayaan PKL di Palembang.

Penelitian ini menggunakan beberapa pendekatan, yaitu pendekatan undang-undang (statute approach), yaitu suatu metode pendekatan yang dilakukan dengan mengkaji peraturan perundang-undangan dan hal yang berkaitan dengan isu hukum yang sedang diteliti (Marzuki, 2005). Pendekatan sosio-legal (socio-legal approach), dengan studi tekstual terhadap peraturan perundang-undangan dan kebijakan secara kritis untuk menjelaskan problematika filosofis, sosiologis dan yuridis dari hukum tertulis dalam pemberdayaan pedagang kaki lima (Shidarta, 2009). Terakhir adalah pendekatan konseptual (conseptual approach), yang beranjak dari adanya pandangan-pandangan dan doktrin-doktrin yang berkembang dalam ilmu hukum. Pandangan-pandangan atau doktrin-doktrin tersebut akan memperjelas ide-ide dengan memberikan pengertian-pengertian hukum, konsep hukum maupun asas-asas hukum yang relevan dalam permasalahan.

Jenis dan sumber data yang digunakan dalam penelitian ini adalah data primer dan data sekunder. Data Primer adalah data yang diperoleh melalui pengamatan langsung, dan wawancara. Data Sekunder adalah data normatif yang bersumber dari peraturan perundangundangan yang berlaku di Indonesia (Khadir, 2011). Penelitian ini juga menggunakan berbagai jenis sumber - sumber bahan - bahan hukum yang berkaitan dengan permasalahan yang diteliti. 
Penelitian ini menggunakan dua jenis pengumpulan data yaitu dengan studi kepustakaan dilakukan dengan pengumpulan data melalui kegiatan studi penelaahan terhadap buku-buku, literatur-literatur yang berkaitan dengan obyek penelitian dan mengkutip dari berbagai data sekunder seperti peraturan perundang-undangan, dokumen dan beberapa bahan kepustakaan lain dari beberapa buku-buku referensi, jurnal-jurnal serta artikel-artikel lainnya serta melalui media massa seperti koran dan internet yang relevan dengan masalah yang diteliti. Kedua, peneliti melakukan studi lapangan dilakukan dengan teknik pengamatan langsung pedagang kaki lima di seputaran Pasar 16 Ilir Kota Palembang, yang didukung dengan teknik wawancara dengan masyarakat sekitar dan pihak-pihak terkait yang relevan dalam masalah penelitian ini yang bertujuan untuk memperoleh data seperti Dinas Tata Kota Palembang, Dinas Perhubungan Kota Palembang, Dinas Perindustrian, Perdagangan dan Koperasi Kota Palembang. Teknik Analisis Data yang sesuai dengan penelitian ini adalah dengan menggunakan pendekatan kualitatif.

\section{PEMBAHASAN}

Di Kota Palembang, pelaksanaan Perpres Nomor 125 Tahun 2012 Tentang Koordinasi Penataan dan Pemberdayaan pedagang kaki lima dilakukan oleh Tim Koordinasi Penataan dan Pemberdayaan Pedagang Kaki Lima yang ditetapkan oleh Walikota Kota Palembang yang berunsurkan kepala satuan kerja perangkat daerah, pelaku usaha, dan asosiasi terkait melalui Peraturan Walikota Palembang Nomor 37 Tahun 2017 Tentang Penataan dan Pemberdayaan Pedagang Kaki Lima, dalam permasalahan ukuran atau tujuan ini sebetulnya sudah cukup realistis diterapkan di Kota Palembang. Dengan adanya Perpres nomor 125 tahun 2012 dan Permendagri nomor 41 tahun 2012, maka Pemerintah Provinsi dan Pemerintah Kota/Kabupaten wajib melakukan penataan dan pembinaan PKL di wilayahnya masing-masing. Salah satu amanat yang tercantum di dalam Permendagri nomor 41 tahun 2012 adalah Bupati/Walikota menetapkan lokasi atau kawasan sesuai peruntukannya sebagai lokasi tempat kegiatan usaha PKL. Penetapan lokasi atau kawasan tempat kegiatan usaha PKL dilakukan dengan memperhatikan kepentingan umum, sosial, budaya, estetika, ekonomi, keamanan, ketertiban, kesehatan, kebersihan lingkungan dan sesuai dengan Peraturan Daerah tentang Rencana Tata Ruang Wilayah Provinsi dan Kabupaten/Kota. Lokasi tempat kegiatan usaha PKL merupakan lokasi binaan Bupati/Walikota yang bersifat permanen atau sementara dan telah dilengkapi dengan papan nama lokasi dan rambu atau tanda yang menerangkan batasan jumlah PKL sesuai dengan peraturan perundang-undangan. 


\section{Pendataan dan Pendaftaran Pedagang Kaki Lima}

Pedagang kaki lima yang ada di Pasar 16 Ilir Palembang ini dibagi menjadi beberapa Unit Pelaksanaan Teknis Pengelolaan Kawasan Pasar 16 berkoordinasi langsung instansi yang menanungi pedagang kaki lima yang ada di kawasan 16 Ilir untuk melaksanakan pendataan pedagang kaki lima namun untuk pendataan dan pendaftaran PKL masih belum terstruktur. Pendataan di kota Palembang umumnya melalui camat yaitu dengan cara membuat daftar usaha bagi PKL untuk berdagang di kawasan dibuat oleh camat dan akan diminta datanya oleh DInas Perdagangan Kota Palembang.

\section{Penetapan Lokasi}

Berdasarkan Perda Kota Palembang 44 Tahun 2002 j.o Perda 13 Tahun 2007 tentang Ketentraman dan ketertiban di Paragraf 5 Pasal 22 tertib usaha dijelaskan pada ayat (1) dan (2) setiap orang atau badan dilarang menempatkan benda-benda dengan maksud untuk melakukan suatu usaha di daerah milik jalan, di jalan, dipinggir rel kereta api, jalur hijau, taman dan tempat-tempat umum, kecuali di tempat yang telah diizinkan oleh kepala daerah, dan setiap orang atau badan dilarang menjajakan barang dagangan, membagikan atau menempelkan selebaran atau melakukan usaha-usaha tertentu dengan mengharapkan imbalan di daerah milik jalan, di jalan, jalur hijau dan taman. Polpp mempunyai kewenangan menurut Perda Kota Palembang 44 Tahun 2002 untuk melakukan penegakan Perda atau tindakan sesuai dengan Perda dan juga bisa melakukan penataan dan pemberdayaan PKL.

\section{Pemindahan dan Penghapusan Lokasi Pedagang Kaki Lima}

Pedagang Kaki Lima (PKL) yang menempati kios dan lapak non permanen di depan Pasar 16 Ilir, membongkar sendiri kios dan lapak tempat mereka biasa menggelar dagangan. Hal ini sesuai hasil negosiasi antara pedagang dan Pemerintah Kota Palembang dalam hal ini PD Pasar untuk melaksanakan relokasi pedagang kaki lima ke lantai 3 pasar 16 Ilir (Sumsel Post, 2019). Sebagaimana dengan instruksi Walikota Palembang Harnojoyo, kawasan Pasar 16 Ilir akan dijadikan pusat wisata malam untuk itu para pedagang di halaman pasar tersebut akan diarahkan ke lantai atas gedung Pasar 16 Ilir. Untuk wilayah yang dilarang keberadaan PKL maka akan dilaksanakan penghapusan lokasi dagang. Contohnya di pasar. Berdasarkan Peraturan Daerah (Perda) Kota Palembang Nomor 13 Tahun 2007, tentang ketentraman dan 
ketertiban umum menyebutkan, jalan protokol, lingkungan pasar harus bebas dari PKL. Berdasarkan hal tersebut dilaksanakan penertiban tegas oleh instansi seperti Satpol PP guna menjalankan amanat dari perda tersebut.

\section{Peremajaan Lokasi Pedagang Kaki Lima}

Proses peremajaan lokasi pedagang kaki lima yang ada di kawasan Pasar 16 Ilir, meliputi peremajaan pada infrastruktur yang rusak dan modal kerja bagi para pedagang kaki lima. Pada sisi peremajaan infrastruktur para pedagang kaki lima berkoordinasi dengan pemilik usaha/ kuasa hak atas bangunan yang lahannya digunakan untuk berjualan pedagang kaki lima guna untuk melakukan perbaikan-perbaikan pada infrastruktur yang rusak. Infrastuktur yang rusak misalnya pada atap atau langit-langit bangunan tempat pedagang kaki lima yang berjualan bocor atau rusak, sehingga perlu adanya peremajaan atau perbaikan. Sesuai dengan Peraturan Presiden No. 112 Tahun 2007 tentang Penataan dan Pembinaan Pasar Tradisional, Pusat Perbelanjaan, dan Toko Modern, serta Peraturan Menteri Perdagangan No. 53 Tahun 2008 tentang Pedoman Penataan dan Pembinaan Pasar Tradisional, Pusat Perbelanjaan dan Toko Modern, maka Pemerintah Kota Palembang perlu memperhatikan kondisi kawasan Pasar 16 Ilir Palembang yang merupakan salah satu aset kota. Pemerintah kota Palembang sendiri telah memiliki rencana pengembangan yang memiliki fokus pada Pasar 16, yakni berupa renovasi serta peningkatkan intensitas bangunan tersebut. Beberapa proposal dari berbagai pihak juga telah diajukan (Skyscraper City, 2007), namun Dinas Tata Kota Palembang belum dapat menyikapi lebih lanjut, karena arahan pengembangan yang belum pasti dari Walikota.

\section{Perencanaan Penyedian Ruang Baru Bagi Kegiatan PKL}

Terbatasnya lapangan pekerjaan dan banyaknya tenaga kerja yang berpendidikan rendah, menyebabkan perkembangan sektor informal dari hari ke hari semakin pesat, begitu juga yang terjadi di Kota Palembang. Pedagang kaki lima ini berpusat di sekitar kawasan Pasar 16 Ilir, yang paling strategis untuk berdagang karena berada di pusat kota dan pusat perdagangan di Kota Palembang. Pedagang kaki lima ini menyebabkan kawasan Pasar 16 Ilir menjadi macet, kotor, bau dan semerawut. Hal ini mendorong pemerintah Kota Palembang untuk merelokasi PKL tersebut ke lokasi baru. Lokasi yang dipersiapkan yaitu Pasar Retail Jakabaring. 
Pasar Retail Jakabaring didirikan untuk menampung pedagang kaki lima yang berasal dari Pasar 16 Ilir Palembang, namun sejalan perkembangannya pasar ini dihuni $80 \%$ dari pedagang yang terkena relokasi dan sisanya 20\% dihuni oleh pedagang pasar lain dan pedagang baru. Untuk biaya sewa yaitu sebesar Rp 100.000,-per bulan dan jika dibandingkan dengan Pasar 16 Ilir lebih berat, selain membayar biaya sewa ada juga pungutan liar. Untuk itu dihrapkan Pasar Retail ini dapat menjadi salah satu solusi terhadap PKL di Kota Palembang.

\section{KESIMPULAN}

Implementasi Perpres Nomor 125 Tahun 2012 Tentang Koordinasi Penataan dan Pemberdayaan Pedagang Kaki Lima Secara Yuridis dan Institusional Di Kota Palembang di lakukan oleh beberapa Instansi di Kota Palembang sama dilaksanakan dengan dibentuk Tim Koordinasi Penataan dan Pemberdayaan Kaki Lima yang ditetapkan oleh Walikota Palembang yang berunsurkan kepala satuan kerja perangkat daerah yang berkoordinasi satu sama lain yakni Satuan Polisi Pamong Praja (Satpol PP), Dinas Perhubungan Kota Palembang, Dinas Perdagangan Kota Palembang dengan cara melakukan Pendataan dan Pendaftaran Pedagang kaki lima, Penetapan Lokasi, Pemindahan dan Penghapusan Lokasi Pedagang Kaki Lima, Peremajaan Lokasi Pedagang Kaki Lima, Perencanaan Penyedian Ruang Baru Bagi Kegiatan PKL, Penetapan Kebijakan penataan PKL, Penetapan Lokasi dan/atau kawasan tempat berusaha PKL di dalam Rencana Detail Tata Ruang, Penataan PKL Melalui Kerja sama antar Pemerintah Daerah, Pengembangan Kemitraan dengan Dunia Usaha, dan Penyusunan program dan kegiatan penataan PKL ke dalam dokumen perencanaan pembangunan daerah, belum sepenuhnya terlaksana dengan baik karena belum terlaksananya beberapa program kerja yang dilakukan oleh instansi terkait mengenai penataan dan pemberdayaan pedagang kaki lima di Kota Palembang seperti dalam penataan pedagang kaki lima belum dilakukannya intensitas tata ruang dan fasilitas bagi pedagang kaki lima di Kota Palembang serta belum melaksanakan pengembangan dunia usaha melalui Program kerjasama bagi pedagang kaki lima di Kota Palembang dengan Mitra Usaha perusahaanperusahaan lainnya di Kota Palembang yang belum diikuti Pemda lainnya di seluruh Indonesia termasuk Palembang. 


\section{DAFTAR PUSTAKA}

Khadir, Abdul Muhammad. (2004). Hukum dan Penelitian Hukum, Bandung: PT. Citra Aditya Bakti, hlm.52.

Nasution, Bahder Johan. (2008). Metode Penelitian Ilmu Hukum, Bandung: Mandar Maju, hlm.174.

Firdausy, C. (1995). Model \& Kebijakan Pengembangan Sektor Informal. Pedagang Kaki Lima di Perkotaan. Jakarta: Dewan Riset Nasional \&. Bappenas.

Permadi, Gilang. (2007). Pedagang Kaki Lima, Riwayatmu dulu, Nasibmu kini. Jakarta: Yudistira, hlm.5.

Hukum Online, 2017. Operasi Keamanan dan Ketertiban, Operasi Dua Muka. http://m.hukumonline.com/berita/baca/hol2566/operasi-keamanan-dan-ketertibanoperasi-dua-muka.

Pena, S. (1999). "Informal Markets: Street Vendors in Mexico City". Habitat International 23(3): 363372.

Peraturan Daerah Kota Palembang Nomor 13 Tahun 2007 tentang Ketentraman dan Ketertiban Umum.

Marzuki, Peter Mahmud. (2005). Penelitian Hukum, Jakarta: Kencana Penada Media Group, hlm. 95.

Skyscraper City. (2007). www.skyscrapercity.com/archive/index.php/t-518447-p6.html.

Irianto, Sulistyowati \& Shidarta. (2009) Metode Penelitian Hukum, Konstelasi dan Refleksi, Jakarta: Yayasan Obor Indonesia, hlm. 177.

Sumsel Post, 2017. Pasar 16 Ilir Bersih dari Kios PKL. http://sumselpostonline.com/pasar-16ilir-bersih-dari-kios-pkl/.

Wikipedia, 2017. Kota Palembang. https://id.m.wikipedia.org/wiki/Kota_Palembang. 